\title{
Preface: Beginnings, Backlash, and Brazenness
}

My goal to explore the history of erotic entertainment - burlesque, gogo dancing, and striptease - has deep personal and political roots. I was born in 1959, at the end of the baby boom, in the northern mining town of Sudbury, Ontario. The eldest of five in a white, middle-class family, I grew up in a lakeside home built on the submerged cement pilings of an early-twentieth-century brothel and dance hall: a fitting foundation for my emergent passions. Since the late 1970s, I have lobbied for women's reproductive choice, lesbian/gay/bisexual liberation, and the rights of trans people (transgender, transsexual, and intersexed) to dignity and equality. I have agitated for access to state-confiscated queer pornography, funding for HIV/AIDS research and education, the decriminalization of prostitution, an end to systemic racism, and the joys of masturbation. While writing this book, I learned that my attraction to striptease is linked to my fierce, abiding love of athleticism, fashion, and music; my queer search for femme ancestors; and my escape from the poisonous, anti-sex venom of Catholicism. For me, compelled by all things erotic, excavating the complexities of 'bump and grind' became one strategy for combating the legacy of sexual shame, guilt, and silence imposed on all women who dare to push against the river of social conformity.

At seventeen, I attended the Folies-Bergère cabaret in Paris. At twenty-seven, I sat in awe of striptease artist Gwendolyn as she irreverently instructed male patrons in the mechanics of female orgasm at Le Strip on Yonge Street, Toronto's famed sin strip. ${ }^{1}$ At thirty-seven, a resident of Vancouver in the late 1990s, I began frequenting strip shows at the No. 5 Orange, the Penthouse Cabaret, and the Cecil Hotel, with my lover Tracy at my side. And at forty-seven, I volunteered at the strip-a- 
thon organized by Exotic Dancers for Cancer to raise money for 'Rethink Breast Cancer' at Vancouver's Drake Show Lounge. After four decades, I am captivated, still, by female dancers' combination of glamour, sexiness, talent, skills, and ingenious use of costumes, props, and music. As a lesbian eager to witness other feminine women's sexy manipulations of femininity, I rarely feel aroused in strip clubs; rather, I identify with, and feel inspired by, stripteasers' public displays of sexual confidence.

Over years of research, I eagerly absorbed knowledge of retired dancers' efforts to achieve economic independence, to defend their craft as bold artistic expression, and to free their bawdy acts from the censorious, punishing gaze of politicians, journalists, clergy, police, criminologists, and feminist critics. The strip trade was (and is) a jumble of contradictions: it promised women more lucrative dividends than sales, service, or clerical work at the same time that it produced them as dangerous sexual 'Others'. Learning how dancers strove to reconcile these duelling poles of adulation and contempt became one of my principal preoccupations.

\section{Plumbing the Irreverent}

To chronicle the history of striptease after World War II, I needed research dollars. In June 1999, after two unsuccessful bids, I was awarded a grant totalling $\$ 50,900$ by the Social Sciences and Humanities Research Council of Canada (SSHRCC). In June 2000, with the help of research assistants Kim Greenwell and Michelle Swann, I spent \$400 on advertising in local community papers and faxing a press release to dozens of media outlets. Our aim was to profile the 'Striptease Project' in order to locate and recruit retired dancers, club owners, booking agents, musicians, choreographers, and photographers. We had encountered great difficulty in finding these folks, in part due to the stigma that still shrouds the business. Also, most of Vancouver's infamous striptease venues had disappeared, with many retired entertainers having left the city. Searching for clues at the provincial archives in Victoria, British Columbia, the City of Vancouver Archives, and the Special Collections archive at the University of British Columbia was like sifting for gold in the Fraser River. Many days we left weary, no wiser than when we entered. We learned that a cloaked, slippery topic like ours would require innovative strategies and some big-time luck.

In June 2000, two journalists, Ken MacQueen from the Vancouver Sun and Dene Moore from Canadian Press, responded to our ad in the Cou- 
rier newspaper. After interviewing me, they played up my 'search for the naked truth.' In a photograph taken outside Vancouver's Penthouse Cabaret, I appear in front of the marquee: 'Pet of the Year' (a dubious distinction at best!) (see plate 1). MacQueen and Moore reported that I had received government funding to write this book. ${ }^{2}$ Their articles were reprinted nationally and internationally, making the front page of the Vancouver Sun, Globe and Mail, National Post, Winnipeg Free Press, Victoria Times Colonist, and most other mainstream newspapers across Canada and the United States, as well as the Bangkok News and the Iran Times. I was subsequently contacted by journalists from across Canada, as well as from Switzerland, Australia, South Africa, California, New York, England, and Scotland. Eight prize-winning documentary filmmakers invited me to collaborate on a film, and I had yet to do the research! Between us, my research assistants and I did forty-five interviews for print, radio, $\mathrm{TV}$, and film/video. ${ }^{3}$

Once I had been contacted by media pundits about my study, I expected a range of titillating angles, but I did not anticipate the relentless personal probing. I stick-handled my way around journalists' shared assumption that I moonlighted as a stripper. I joked that had I danced in strip clubs I would have paid off my student loan two decades earlier! Like a broken record, reporters asked: 'How do you justify spending taxpayers' dollars on studying strippers?' Numerous non-Canadian reporters said they were frankly astonished that (a) I took a 'frivolous' topic so seriously, and (b) I had funding from the public purse. On the media hot seat, I stressed the originality of my project and the need to redress the silences in the province's canonical history. I talked about how the money would fund skills training for my research assistants. Adapting the wisdom of feminist sociologist Dorothy E. Smith, I described my desire to treat former dancers, club owners, and other key players as the experts of their own lives. I outlined my plan to explore the dancers' contribution to local economies and performance traditions. From my preliminary findings, I discovered that ex-dancers had a stake in the allocation of tax dollars for research since they had paid personal income tax and sales tax, and some had invested in Canada Savings Bonds and registered retirement plans.

\section{Righteous, Angry Canadians Sound Off}

I was ill-prepared for the spiteful, even hateful e-mails, phone calls, and faxes. On talk-radio shows in Toronto, Calgary, and Vancouver, I was 
attacked by successive callers who were incensed that the government would 'waste their money' on such a 'useless, disgusting project.' Several male callers ventured that a history of male loggers and miners in British Columbia would be much more constructive. (Of course, they conveniently neglected to acknowledge the instrumental role played by female sex workers in the history of resource-based communities. $)^{4} \mathrm{On}$ the Rafe Mair radio show in Vancouver, a male caller opined, 'I could have told you that men like to drink beer and look at naked women fifty thousand dollars saved. I don't see what the point of this research is. It's a no-brainer, period. ${ }^{5}$ Mark Milke from the Canadian Taxpayers' Federation bellowed that the research 'was a joke.' He was quoted as saying, 'I'm almost speechless. What, strippers don't get "studied" enough every day as it is?' One cameraman at a local television station hissed, behind my back, that I was a stupid fool. In the federal House of Commons in Ottawa, the right-wing Reform party (newly merged with the Progressive Conservative party), castigated the Liberal majority for authorizing such a gross misuse of citizens' monies. Political cartoonists had their way with the scandal (see fig. P1). In the midst of the cacophony, thirty-five letters denouncing my project were sent to then Prime Minister Jean Chrétien and forwarded to my funder. Every letter received by SSHRCC made some reference to the project's funding as a farcical, absurd, worthless, and ridiculous squandering of taxpayers' dollars.

My survey of the sample of complaints reveals two main arguments: approximately half underscored the need to redirect government 'handouts' away from such offensive 'wastage' to more deserving projects: 'I resent hard earned tax dollars going to promote the stripper industry. How will people in need of affordable housing benefit directly from the study?'; 'There isn't an emergency hospital facility in the country that would not have welcomed a $\$ 51,000$ donation'; 'If you can give frivolous grants for studying strippers surely to god you can return some tax money for a worthwhile project like the Toronto transit system'; 'It is unbelievable to us that our government can't cut taxes or lower the GST but can spend money on this nonsense. SHAME!!' And finally, 'This grant has no social value. Have you been down to the east side of Vancouver lately?'

The second, equally popular set of criticisms tackled the content of my study more directly: 'If I want to see someone strip naked, I will bring home a bottle of wine and ask my spouse to strip for me in the privacy of my house, not in some bar'; 'A person who is already struggling 


\section{Image Not Available}

Figure P1 Cartoonist Adrian Raeside lampoons the conservative backlash among Conservative (then Reform party) politicians. Penticton Herald, June 2000.

with moral/mental problems goes to a strip bar ... And we wonder why rape is rampant in Canada. Why not spend that money on seeing how we can stop these people with mental disorders from becoming violent offenders!'; 'Strippers usually don't do much besides perform banally repetitive "dances" in seedy strip joints. Not sure what viable research or "art" can be gleaned from that. What type of professor spends all her time in strip clubs, anyway?' And finally, from a conservative women's organization in Alberta: 'Our goal is to strengthen families, communities and our nation through educational and service programmes. We sincerely hope you will rescind this grant.' Though hardly representative of the views of an entire country's population, the hostile responses were nonetheless disquieting. Canadians, it seemed, were in an ornery mood, no doubt because of worries about the dismantling of social programs and national health care, a looming economic downturn, and the ongoing burden of the Goods and Services Tax (GST). And though 
I share concerns about the erosion of the welfare state, the crisis of poverty, and the wrong-headedness of some government priorities (e.g., national defence funding and corporate tax shelters), my Striptease Project triggered animosity that seemed to far outstrip criticism of other federal spending initiatives.

I quickly realized that the backlash was partly linked to the ongoing scandal inside the ministry of Human Resources Development Canada (HRDC). In February 2000, news outlets across the country reported that an audit alleged that $\$ 30$ million was unaccounted for, and the minister, Jane Stewart, was lambasted for mismanagement of taxpayers' money. ${ }^{6}$ For a federal Liberal government with a reputation for financial competence and fiscal probity, charges of 'wasted money' dealt a serious blow. Though SSHRCC funded my project, not HRDC, it mattered little to exasperated citizens, who demanded that Prime Minister Chrétien veto my grant. I began to feel that academics, university administrators, and scholarly funding agencies need to work harder to make our procedures more transparent and our work more visible and relevant to communities beyond our campus gates. For instance, the council that bankrolls research in Social Sciences and Humanities oversees a highly competitive, peer-review process. The annually dispensed funds have enabled excellent, award-winning research and writing. But I suspect this is cold comfort to those who oppose all public subsidies to makers of history, art, and culture.

What distressed me most about the negative publicity was the popular belief that striptease was something to be ashamed of, stuffed under the carpet, and purged from public discourse. The overriding message: stripteasers were best dismissed as smelly trash, better off disqualified from national conversations about the allocation of tax dollars. Their citizenship status, including their democratic right to debate public policy, was under siege. Dancers were caricatured as anti-family and a threat to national sovereignty. And underlying the prevailing attack on dancers was veiled disgust towards 'sleazy strip joints' and the men who frequented them. My place as a scholar employed at the University of British Columbia - a reputable institute of higher learning - also came under fire as fellow Canadians publicly disapproved of my efforts to 'dignify' such an 'undignified,' even 'undignifiable' subject. Not only was the study deemed worthless, repellent, and unfundable; critics seemed to say that stripteasers were not worthy of anything but collective contempt. In fact, irate naysayers invoked the same impulse to differentiate the 'savage' from the 'civilized' as had misguided co- 
lonial explorers, scientists, politicians, physicians, women's groups, clergy, and journalists a century earlier. ${ }^{7}$

As much as the angry outburst upset us, my assistants and I scored over $\$ 1$ million worth of publicity! Retired dancers and club owners contacted me from all over Canada, and from as far away as Italy, Virginia, Washington, Florida, and California. Emboldened by their desire to be heard above the chattering critics, they expressed a willingness to participate, and to put me in touch with others. In particular, the dancers' enthusiasm for the project assured me that the time was right. Both ex-dancers and other business insiders noted that many original movers and shakers in Vancouver's postwar burlesque and striptease scene had died. I also recognized that those still with us were aging, and that their passing would mean the loss of their memories and memorabilia.

Shaken by the reactionary mean-spiritedness, and disturbed by how strippers were being freakified, I quickly found that the scope and scale of the backlash strengthened my resolve. If ex-dancers were perverts, then I was too, proudly so. Theirs was a story worth telling, not one to be drowned out by barbed misogynist musings about how men's past experiences in timber, mining, and forestry were intrinsically more significant. Convinced of the importance of erotic entertainment as remembered by the women and men once pivotal to its staging, I strove to open up new, fresh terrain for historical inquiry. Pledging to listen to, learn from, and honour the brazen voices of business insiders heretofore disregarded, I plunged in with a thicker skin than when I had first imagined this research more than ten years ago. 
This page intentionally left blank 
BURLESQUE WEST:

SHOWGIRLS, SEX, AND SIN IN POSTWAR VANCOUVER 
This page intentionally left blank 